\title{
Progression of Selective IgA Deficiency to Common Variable Immunodeficiency
}

\author{
Asghar Aghamohammadi ${ }^{a} \quad$ Javad Mohammadi $^{b} \quad$ Nima Parvaneh $^{a}$ \\ Nima Rezaei ${ }^{a}$ Mostafa Moin ${ }^{a}$ Teresa Espanol ${ }^{c}$ Lennart Hammarstrom ${ }^{b}$

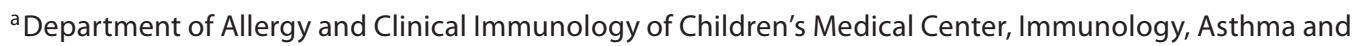 \\ Allergy Research Institute, Tehran University of Medical Sciences, Tehran, Iran; ${ }^{b}$ Division of Clinical Immunology, \\ Department of Laboratory Medicine, Karolinska Institutet, Karolinska University Hospital Huddinge, Stockholm, \\ Sweden; 'Department of Immunology and Immunodeficiencies, Hospital Vall d'Hebron, School of Medicine, \\ Barcelona, Spain
}

\section{Key Words \\ Common variable immunodeficiency $\cdot \lg A$ deficiency $•$ Antibody deficiency}

\begin{abstract}
Selective IgA deficiency (IgAD) is the most common primary immunodeficiency in Caucasians. Although it is often asymptomatic, selected patients show an increased frequency of infections, allergies and autoimmune manifestations. Common variable immunodeficiency (CVID) is a primary antibody deficiency disease that shares many clinical features with IgAD. A common genetic basis for IgAD and CVID has been suggested based on their occurrence in members of the same family and the similarity of the underlying $B$ cell defects. Progression from IgAD to CVID has also been reported in several cases. Here we present 4 patients with $\lg A D$ and autoimmune features who subsequently developed CVID. All symptomatic IgAD patients, especially those with associated IgG subclass deficiency or autoimmune features, should be monitored for evolution to CVID. Early diagnosis of this conversion and institution of immunoglobulin therapy is effective in preventing severe bacterial infections and pulmonary insufficiency. Copyright $\odot 2008$ S. Karger AG, Basel
\end{abstract}

\begin{tabular}{ll}
\hline KARGER & @ 2008 S. Karger AG, Basel \\
$1018-2438 / 08 / 1472-0087 \$ 24.50 / 0$ \\
$\begin{array}{l}\text { Fax +4161306 1234 } \\
\begin{array}{l}\text { E-Mail karger@karger.ch } \\
\text { www.karger.com }\end{array}\end{array}$ & $\begin{array}{l}\text { Accessible online at: } \\
\text { www.karger.com/iaa }\end{array}$
\end{tabular}

\section{Introduction}

Selective IgA deficiency (IgAD) is the most common primary immunodeficiency disorder and is characterized by decreased serum IgA concentration of $<0.07 \mathrm{~g} / \mathrm{l}$ and normal serum IgM and IgG levels [1]. Many of these individuals have no apparent disease, whereas selected patients suffer from recurrent mucosal infections, allergies and autoimmune diseases [2]. The defect is presumed to result from impaired switching to IgA or a maturational failure of IgA-producing lymphocytes.

Common variable immunodeficiency (CVID) is a primary antibody deficiency disease characterized by low serum levels of IgG, IgA and/or IgM, and normal or decreased $\mathrm{B}$ cell numbers leading to recurrent infections noted mostly in the respiratory and gastrointestinal tract [1, 3-5]. The pathogenesis of CVID still remains unknown. It seems that a defect in B cell differentiation leads to impaired secretion of immunoglobulins in the patients. Abnormalities of T cells and dendritic cells have also been reported in some patients [6-9].

A common genetic basis for IgAD and CVID has been suggested by their occurrence in members of the same family and the similarity of the underlying $B$ cell defect [10]. Progression from IgAD to CVID has also been reported in several cases [11-13].

Correspondence to: Prof. Asghar Aghamohammadi

Department of Allergy and Clinical Immunology of Children's Medical Center Immunology, Asthma and Allergy Research Institute

No. 62, Dr. Gharib St, Keshavarz Blvd, PO Box 14185-863, Tehran 14194 (Iran)

Tel. +98 216693 5855, Fax +98 216642 8995, E-Mail aghamohammadi@sina.tums.ac.ir 
Table 1. Laboratory findings of IgAD patients who progressed to CVID

\begin{tabular}{|c|c|c|c|c|c|c|c|c|c|c|}
\hline Patient No. & Country & HLA & Date & $\operatorname{IgM}$ & $\operatorname{IgG}$ & $\operatorname{Ig} A$ & IgG1 & IgG2 & IgG3 & IgG4 \\
\hline \multirow[t]{5}{*}{1} & \multirow[t]{5}{*}{ Sweden } & \multirow{5}{*}{$\begin{array}{l}\text { A1,1 } \\
\text { B8,8 } \\
\text { DR3,3 } \\
\text { DQ2,2 }\end{array}$} & $01 / 12 / 1982$ & 0.34 & 5.0 & $<0.05$ & 2.92 & 0.03 & 0.39 & $<0.0$ \\
\hline & & & $11 / 12 / 2003$ & $<0.04$ & 1.65 & $<0.02$ & - & - & - & - \\
\hline & & & $03 / 02 / 2004$ & 0.04 & 1.57 & $<0.06$ & 1.17 & $<0.08$ & 0.23 & $<0.03$ \\
\hline & & & $06 / 23 / 2004$ & $<0.17$ & $7.26^{1}$ & $<0.06$ & 4.17 & 3.06 & 0.30 & $<0.03$ \\
\hline & & & 03/03/2005 & $<0.04$ & $8.04^{1}$ & $<0.06$ & - & - & - & - \\
\hline \multirow[t]{5}{*}{2} & \multirow{5}{*}{ Sweden } & & 01/16/1992 & 0.56 & 4.9 & 0.01 & - & - & - & - \\
\hline & & $\mathrm{B} 8,47$ & 05/11/1992 & 0.3 & 6.0 & $<0.07$ & 3.5 & 2.0 & 0.3 & $<0.05$ \\
\hline & & DR3,4 & 08/27/1998 & 0.4 & 4.3 & 0.08 & 2.5 & 1.8 & 0.6 & 0.27 \\
\hline & & DQ2,3 & $11 / 20 / 2001$ & 0.09 & $11.3^{1}$ & $<0.06$ & 5.37 & 5.11 & 0.35 & 0.06 \\
\hline & & & 04/07/2004 & 0.07 & $10.1^{1}$ & $<0.06$ & 6.25 & 4.96 & 0.36 & 0.04 \\
\hline \multirow[t]{4}{*}{3} & \multirow[t]{4}{*}{ Iran } & $\mathrm{A} 2,29$ & 08/15/1998 & 1.12 & 14.7 & 0 & - & - & - & - \\
\hline & & $\mathrm{B} 7,51$ & $04 / 20 / 2000$ & 0.8 & 8.6 & 0 & 6.72 & 0.51 & 0.6 & 0.03 \\
\hline & & DR3,11 & $07 / 29 / 2002$ & 0.2 & 3.4 & 0 & - & - & - & - \\
\hline & & DQ2,3 & $02 / 26 / 2004$ & 0.4 & 4.89 & 0 & 2.87 & 0.79 & 0.23 & 0.2 \\
\hline \multirow[t]{3}{*}{4} & \multirow[t]{3}{*}{ Spain } & $\mathrm{A} 1,2$ & 1994 & 0.85 & 9.84 & 0 & 6.00 & 2.20 & 0.43 & 0.04 \\
\hline & & B58,58 & 2001 & 0.25 & 4.40 & 0 & 3.60 & 0.02 & 0.30 & 0.1 \\
\hline & & DR7,13 & $2005^{1}$ & 0.15 & 7.53 & 0 & 5.12 & 2.63 & 0.42 & 0.3 \\
\hline
\end{tabular}

Data are presented as grams per liter. ${ }^{1}$ Gamma globulin substituted.

In addition, fixed haplotypes of MHC genes are frequently associated with both IgAD and CVID. At least 2 distinct loci, 1 in the class II region and 1 in the class III region, confer susceptibility to the development of IgAD and CVID $[3,14]$. The extended haplotype HLA-A1, B8, DR3 has been shown to be associated with both IgAD and CVID [10].

Two studies have recently reported that coding variants in TNFRSF13B, which encodes transmembrane activator and CAML interactor (TACI), are associated with CVID and $\operatorname{IgAD}[15,16]$.

IgA deficiency is associated with some autoimmune diseases such as systemic lupus erythematosus, juvenileonset diabetes mellitus and rheumatoid arthritis [17-19]. Homozygosity for the HLA B8, DR3, DQ2 haplotype or part of this haplotype is a risk factor for development of some autoimmune diseases [20-26].

Early diagnosis of conversion from IgAD to CVID and institution of immunoglobulin therapy is effective in preventing severe bacterial infections and pulmonary insufficiency [27]. Here we present 4 patients with IgAD that progressed to CVID, and review the reported cases in the medical literature to search for the effect of some factors such as HLA and autoimmune association [11-13, 28 36].

\section{Materials and Methods}

\section{Study Population}

The study was approved by the Tehran University of Medical Sciences and the Karolinska Institute in Stockholm. The clinical records of all immunodeficient patients were reviewed in these clinics for the past 20 years. Four patients are described here (2 Swedish, 1 Iranian and 1 Spanish).

\section{Serum Immunoglobulin Levels}

Serum immunoglobulin levels were determined by ELISA and nephelometry using goat polyclonal antisera. A sample was considered IgAD if the concentration of IgA was $<0.07 \mathrm{~g} / \mathrm{l}$. The diagnosis of CVID was made when serum levels of at least 2 serum immunoglobulin isotypes ( $\operatorname{IgG}, \operatorname{IgM}$ and $\operatorname{IgA}$ ) were lower than normal $[37,38]$.

\section{HLA Typing}

Samples were genotyped at the HLA A, B, DR and DQ loci by PCR-SSP [39]. Analysis of the TNFRSF13B gene (sequencing or analysis of disease-associated SNPs) was performed as described previously [16].

\section{Case Reports}

Patient 1

A 62-year-old man was identified as IgAD in 1974 during a routine screening of Swedish blood donors. Initially, he did not 
Table 2. Characteristics of reported IgAD patients who progressed to CVID

\begin{tabular}{|c|c|c|c|c|c|c|c|}
\hline \multirow[t]{2}{*}{ Case } & \multirow[t]{2}{*}{ Sex } & \multirow{2}{*}{$\begin{array}{l}\text { Interval } \\
\text { of pro- } \\
\text { gression } \\
\text { years }\end{array}$} & \multicolumn{4}{|l|}{ Characteristics of individual patients } & \multirow[t]{2}{*}{ Ref. } \\
\hline & & & clinical finding & immunological abnormalities & genetic association & $\begin{array}{l}\text { family } \\
\text { history }\end{array}$ & \\
\hline P1 & $\mathrm{F}$ & 27 & sinusitis, dermatitis, oral candidiasis, ITP, vitiligo & HIV infection, CD4 lymphopenia & 18q deletion & - & 12 \\
\hline $\mathrm{P} 2$ & $\mathrm{~F}$ & 6 & weight loss, chronic active hepatitis, vitiligo & NA & $\begin{array}{l}\text { HLA A11,24, B38,39, } \\
\text { DR3,4 }\end{array}$ & - & 11 \\
\hline P3 & $\mathrm{F}$ & 1 & $\begin{array}{l}\text { respiratory infection, systemic lupus } \\
\text { erythematosus }\end{array}$ & $\begin{array}{l}\text { ANA, anti-dsDNA, Antihiston, } \\
\text { antimicrosomal }\end{array}$ & $\begin{array}{l}\text { HLA A3,26, B18,51, } \\
\text { DR1,4 }\end{array}$ & - & 11 \\
\hline$\overline{\mathrm{P} 4}$ & $\mathrm{~F}$ & 12 & respiratory and gastrointestinal infections & IgG2 deficiency & NA & - & 11 \\
\hline $\mathrm{P} 5$ & M & 5 & recurrent pneumonia and tonsillitis & IgG2 and IgG4 deficiency & NA & NA & 13 \\
\hline$\overline{\mathrm{P} 6}$ & M & 4 & recurrent infections & CD4 lymphopenia & NA & NA & 13 \\
\hline P7 & $\mathrm{F}$ & 9 & pneumonia, diabetes mellitus, thyroiditis & IgG2 and IgG3 deficiency & 18q deletion & NA & 32 \\
\hline P8 & $\mathrm{F}$ & 5 & $\begin{array}{l}\text { recurrent infections, ITP, autoimmune hemolytic } \\
\text { anemia, Sjogren's syndrome }\end{array}$ & CD4 deficiency & NA & NA & 29 \\
\hline P9 & M & 1.5 & recurrent pneumonia & CD4/CD8 decreased & NA & + & 30 \\
\hline $\mathrm{P} 10$ & $\mathrm{~F}$ & 4 & respiratory infections, diarrhea, alopecia & NA & NA & NA & 31 \\
\hline P11 & $\mathrm{F}$ & - & recurrent infections, chronic ITP & IgG2 and IgG4 deficiency & NA & + & 33 \\
\hline P12 & M & 8 & recurrent sinusitis & IgG2 and IgG4 deficiency & HLA A1, B8, DR3,4 & + & 34 \\
\hline P13 & M & 2 & recurrent sinusitis, otitis media & IgG2 and IgG4 deficiency & $\begin{array}{l}\text { HLA A1,31, B7,8, } \\
\text { DR2,3 }\end{array}$ & NA & 34 \\
\hline $\mathrm{P} 14$ & $\mathrm{~F}$ & 15 & sinusitis, otitis media, bronchitis & NA & $\begin{array}{l}\text { HLA A1,2, B44,49, } \\
\text { DR7,13 }\end{array}$ & - & 34 \\
\hline$\overline{\mathrm{P} 15}$ & M & 7 months & $\begin{array}{l}\text { ulcerative colitis, amyloid changes, non-A/non-B } \\
\text { hepatitis, bronchopneumonia, lichen planus }\end{array}$ & low B cells; defect in B and T cells & ND & - & 35 \\
\hline $\mathrm{P} 16$ & $\mathrm{M}$ & 11 & $\begin{array}{l}\text { sarcoidosis, respiratory tract infection, } \\
\text { bronchopneumonia }\end{array}$ & low B cells & $\begin{array}{l}\text { HLA B7,40, DR4,4, } \\
\text { DQ3,3 }\end{array}$ & NA & 35 \\
\hline$\overline{\mathrm{P} 17}$ & M & 4 & $\begin{array}{l}\text { respiratory tract infection, measles, pneumonia, } \\
\text { diarrhea }\end{array}$ & $\begin{array}{l}\text { B cell defect; decreased number } \\
\text { of CD20 cells; IgG1, 2, 3, } 4 \\
\text { deficiency }\end{array}$ & & NA & 34 \\
\hline P18 & M & 7 & ITP & $\begin{array}{l}\text { IgG subclass deficiency and low } \\
\text { isohemaglutinins; nonreactive } \\
\text { DHST, transient antithyroid and } \\
\text { antiplatelet Ab }\end{array}$ & - & NA & 28 \\
\hline P19 & $\mathrm{F}$ & 15 & respiratory tract infection, nephrotic syndrome & $\begin{array}{l}\text { IgG subclass deficiency and low } \\
\text { isohemaglutinins; nonreactive } \\
\text { DHST, transient antithyroid and } \\
\text { antiplatelet } \mathrm{Ab}\end{array}$ & - & NA & 28 \\
\hline $\mathrm{P} 20$ & $\mathrm{~F}$ & 7 & pneumonia, JRA, thyroiditis & $\begin{array}{l}\text { IgG subclass deficiency and low } \\
\text { isohemaglutinins; nonreactive } \\
\text { DHST, transient antithyroid and } \\
\text { antiplatelet Ab }\end{array}$ & - & NA & 28 \\
\hline
\end{tabular}

ITP = Idiopathic thrombocytopenic purpura; ANA = antinuclear antibody; DHST = delayed hypersensitivity skin test; ND = not determined; Ab = antibody; JRA = juvenile rheumatoid arthritis; NA = not available.

experience increased infection susceptibility. However, a few years ago, he noted an increased proneness and a longer duration of infections, especially in the upper respiratory tract. Haemophilus influenzae was a common inciting organism. He was then diagnosed as CVID. Nevertheless, he had antibody against tetanus and diphtheria due to vaccination (table 1). He was adopted, thus no family history could be obtained. No mutations in the disease-associated TNFRSF13B SNPs (C104R, A181E, R202H) could be identified.

\section{Patient 2}

A 53-year-old man was prone to otitis media during childhood but had no major infections until 1991. He had a previous history of mild psoriasis and influenza in 1991, when IgA deficiency was 
detected by chance. He was referred to our clinic in Sweden in 1992 for evaluation. The patient is diabetic, as is his aunt and maternal grandmother. He was initially followed up without any treatment. Then, immunoglobulins started to drop, suggesting CVID (table 1) and gamma globulin treatment was started in 2001. Mutation analysis revealed no disease-associated mutations in TNFRSF13B.

\section{Patient 3}

A 21-year-old woman, the second child of consanguineous parents without a family history of immunodeficiency, had a history of recurrent infections from early childhood. Her medical problems began during infancy with allergic dermatitis, followed after 1 year by chronic diarrhea and frequent episodes of upper respiratory infections, including sinusitis and otitis media. At the age of 3 , she was diagnosed with myasthenia gravis. At the age of 12 , she was diagnosed with hypothyroidism and since that time, she has been treated with levothyroxin. At the age of 15, she developed a severe pneumonia and was hospitalized in the Children's Medical Center in Tehran for further evaluation, which showed undetectable IgA and diminished IgG2 in serum. Within 2 years of follow-up, serum levels of IgG and IgM showed a gradual decline and she subsequently developed bronchiectasis. From this point onwards she was considered to have CVID and has been substituted with intravenous immunoglobulin (table 1). Because of chronic diarrhea and growth retardation, a gastrointestinal biopsy was performed, which showed intestinal inflammation and subtotal villous atrophy.

\section{Patient 4}

A 20-year-old woman was admitted to hospital because of repeated episodes of diarrhea and respiratory infections, which improved with antibiotics. There was a history of juvenile rheumatoid arthritis in her brother. At the age of 14, she suffered from pneumonia, and IgAD with lymphoid nodular hyperplasia in the small intestine was diagnosed. No specific therapy except antibiotics and diet was given. She was referred again at the age of 26 , due to persistent respiratory and gastrointestinal infections (Giadia lamblia and Salmonella enteritidis) with a decline in IgG, IgM and IgG2 levels, and a very poor response to pneumococcal vaccination. Consequently, CVID was diagnosed (table 1). She has been on intravenous immunoglobulin therapy since then and her clinical manifestations have improved greatly. Mutation analysis revealed no disease-associated mutation in TNFRSF13B.

\section{Discussion}

The characteristics and intervals until development of CVID in IgAD patients in previously published studies are summarized in table 2. The true number of cases is, however, probably much higher than that reported in the literature.

Progression of IgAD to CVID occurs in some families, but is not a general rule. On the other hand, it is postulated that only a subset of CVID is genetically related to IgAD; these are likely CVID cases with IgAD/CVID rel- atives [10, 40,41]. Although we did not study antibody responses against polysaccharide vaccines in all patients, it seems that some CVID patients can produce protective postvaccination titers [42], in contrast to the general notion that patients with CVID respond poorly to vaccination [38]. IgAD is occasionally associated with IgG subclass deficiency that may lead to bacterial infections and could signal the onset of CVID [43-46]. All but 2 of the reviewed cases had respiratory infectious manifestations, $47 \%$ had IgG2 subclass deficiency, indicating a gradual onset of CVID (table 2). Mutations of the gene TNFRSF13B encoding TACI have been found in some patients with CVID and IgAD $[15,16,47]$. However, the role of TNFRSF13B mutations in isolated IgAD has recently been challenged $[48,49]$. No disease-associated mutations in TNFRSF13B were found in the 3 patients analyzed in this paper.

Co-occurrence of psoriasis and myasthenia gravis in our patients (table 1) and the frequency of $42 \%$ of IgAD patients with autoimmune disorders (table 2) suggest that autoimmunity could be a risk factor for progression to CVID.

Some extended MHC haplotypes such as HLA B8, DR3, that are unique in their association with a large number of autoimmune disorders, have also been found in increased frequency in both IgAD and CVID [10, 20, 50-53]. Our patients and others who have progressed from IgAD to CVID and have been HLA typed, share some alleles of these extended haplotypes (table 1). Several other extended haplotypes are increased in frequency among IgAD and CVID patients, including HLA A28, B14 and HLA A1, B8 [14, 44, 45, 54].

Homozygosity for HLA A1, B8, DR3, DQ2, or part of this haplotype, is a risk factor for development of IgAD, CVID and some autoimmune diseases such as celiac disease, myasthenia gravis, Graves' disease and systemic lupus erythematosus $[10-12,32,50,55]$. Patient 1 is homozygous for HLA B8, DR3, DQ2 and patient 2 is heterozygous for this haplotype. Patient 3 is heterozygous for DR3, DQ2 (table 1). Thus, HLA A1, B8, DR3 and DQ2 homozygosity or heterozygosity in IgAD patients could be one of the factors that may be important for the progression to CVID.

\section{Conclusion}

Co-occurrence of some autoimmune disorders, IgG subclass deficiency and association of the HLA A1, B8, DR3, DQ2 or part of this haplotype in IgAD patients, in 
particular those with affected family members, could be risk factors for induction of CVID, and monitoring these patients as well as substitution with gamma globulin could be effective for limitation of the signs and symp- toms. It could be recommended that all symptomatic patients with IgAD should be carefully monitored for possible progression to CVID. Family studies in such a group of patients are also suggested.

\section{References}

1 Hammarstrom L, Vorechovsky I, Webster D: Selective IgA deficiency (SIgAD) and common variable immunodeficiency (CVID). Clin Exp Immunol 2000;120:225-231.

$\checkmark 2$ Burrows PD, Cooper MD: IgA deficiency. Adv Immunol 1997;65:245-276.

-3 Schroeder HW Jr, Schroeder HW 3rd, Sheikh SM: The complex genetics of common variable immunodeficiency. J Investig Med 2004; 52:90-103.

4 Cunningham-Rundles C, Bodian C: Common variable immunodeficiency: clinical and immunological features of 248 patients. Clin Immunol 1999;92:34-48.

$\checkmark 5$ Aghamohammadi A, Farhoudi A, Moin M, Rezaei N, Kouhi A, Pourpak Z, Yaseri N, Movahedi M, Gharagozlou M, Zandieh F, Yazadni F, Arshi S, Mohammadzadeh I, Ghazi BM, Mahmoudi M, Tahaei S, Isaeian A: Clinical and immunological features of 65 Iranian patients with common variable immunodeficiency. Clin Diagn Lab Immunol 2005; 12:825-832.

6 Wehr C, Kivioja T, Schmitt C, Ferry B, Witte T, Eren E, Vlkova M, Hernandez M, Detkova D, Bos PR, Poerksen G, von Bernuth H, Baumann U, Goldacker S, Gutenberger S, Schlesier M, Bergeron-van der Cruyssen F, Le Garff M, Debre P, Jacobs R, Jones J, Bateman E, Litzman J, van Hagen PM, Plebani A, Schmidt RE, Thon V, Quinti I, Espanol T, Webster AD, Chapel H, Vihinen M, Oksenhendler E, Peter HH, Warnatz K: The EUROclass trial: defining subgroups in common variable immunodeficiency. Blood 2008;111:77-85.

7 Ravanbakhsh M, Sarafnejad A, Aghamohammadi A, Kardar GA, Asgarian Omran H, Atarod L, Rezaei N, Shahrestani T, Hosseini M, Moin M: CD40 ligand expression on stimulated T-helper lymphocytes in patients with common variable immunodeficiency. Iran J Allergy Asthma Immunol 2007;6:129135.

8 Nourizadeh M, Aghamohammadi A, Moazzeni SM, Mahdavi M, Rezaei N, Hadjati J: High production of IL-18 by dendritic cells induced by sera from patients with primary antibody deficiency. Iran J Allergy Asthma Immunol 2007;6:59-65.
$>9$ Vodjgani M, Aghamohammadi A, Samadi M, Moin M, Hadjati J, Mirahmadian M, Parvaneh N, Salavati A, Abdollahzade S, Rezaei N, Srrafnejad A: Analysis of class-switched memory B cells in patients with common variable immunodeficiency and its clinical implications. J Investig Allergol Clin Immunol 2007; 17:321-328.

10 Schroder HW Jr, Zhu ZB, March RE, Campbell RD, Berney SM, Nedospasov SA, Turestsakaya RL, Atkinson TP, Go RC, Cooper MD, Volanakis JE: Susceptibility locus for IgA deficiency and common variable immunodeficiency in the HLA-DR3, B8, A1 haplotype. Mol Med 1998;4:72-86.

11 Espanol T, Catala M, Hernandez M, Caragol I, Bertran JM: Development of a common variable immunodeficiency in IgA-deficient patients. Clin Immunol Immunopathol 1996;80:333-335.

12 Gutierrez MG, Kirkpatrick CH: Progressive immunodeficiency in a patient with IgA deficiency. Ann Allergy Asthma Immunol 1997;79:297-301.

13 Carvalho Neves Forte W, Ferreira De Carvalho Junior F, Damaceno N, Vidal Perez F, Gonzales Lopes C, Mastroti RA: Evolution of IgA deficiency to IgG subclass deficiency and common variable immunodeficiency. Allergol Immunopathol (Madr) 2000 28:1820.

14 Schaffer FM, Palermos J, Zhu ZB, Barger BO, Cooper MD, Volanakis JE: Individuals with IgA deficiency and common variable immunodeficiency share polymorphisms of major histocompatibility complex class III genes. Proc Natl Acad Sci USA 1989;86:8015-8019.

15 Castigli E, Wilson S, Garibyan L, Rachid R, Bonilla F, Schneider L, Geha R: TACI is mutant in common variable immunodeficiency and IgA deficiency. Nat Genet 2005;37:829834.

16 Salzer U, Chapel HM, Webster ADB, PanHammarström Q, Schmitt-Graeff A, Schlesier M, Peter HH, Rockstroh JK, Schneider P, Schäffer AA, Hammarström L, Grimbacher B. Mutations in TNFRSF13B, which encodes TACI, are associated with Common Variable Immunodeficiency in humans. Nat Genet 2005;37:820-828.

17 Cassidy JT, Burt A, Petty R, Sullivan D: Selective IgA deficiency in connective tissue diseases. N Engl J Med 1969;280:275.
18 Cleland LG, Bell DA: The occurrence of systemic lupus erythematosus in two kindreds in association with selective IgA deficiency. J Rheumatol 1978;5:288-293.

19 Smith WI, Jr., Rabin BS, Huellmantel A, Van Thiel DH, Drash A: Immunopathology of juvenile-onset diabetes mellitus. I. IgA deficiency and juvenile diabetes. Diabetes 1978; 27:1092-1097.

20 Ploski R, Ek J, Thorsby E, Sollid LM: On the HLA-DQ $\left(\alpha 1^{*} 0501, \beta 1^{*} 0201\right)$-associated susceptibility in celiac disease: a possible gene dosage effect of DQB ${ }^{*} 0201$. Tissue Antigens 1993;41:173-177.

21 Mearin ML, Biemond I, Pena AS, Polanco I, Vazquez C, Schreuder GT, de Vries RR, van Rood JJ: HLA-DR phenotypes in Spanish coeliac children: their contribution to the understanding of the genetics of the disease. Gut 1983;24:532-537.

22 Ploski R, Ascher H, Sollid LM: HLA genotypes and the increased incidence of coeliac disease in Sweden. Scand J Gastroenterol 1996;31:1092-1097.

23 Demarchi M, Carbonara A, Ansaldi N, Santini B, Barbera C, Borelli I, Rossino P, Rendine S: HLA-DR3 and DR7 in coeliac disease: immunogenetic and clinical aspects. Gut 1983;24:706-712.

24 Plesner A, Greenbaum CJ, Gaur LK, Ernst RK, Lernmark A: Macrophages from highrisk HLA-DQB1*0201/*0302 type 1 diabetes mellitus patients are hypersensitive to lipopolysaccharide stimulation. Scand J Immunol 2002;56:522-529.

25 Rani R, Sood A, Lazaro AM, Stastny P: Associations of MHC class II alleles with insulin-dependent diabetes mellitus (IDDM) in patients from North India. Hum Immunol 1999;60:524-531.

26 Zavattari P, Lampis R, Motzo C, Loddo M, Mulargia A, Whalen M, Maioli M, Angius E, Todd JA, Cucca F: Conditional linkage disequilibrium analysis of a complex disease superlocus, IDDM1 in the HLA region, reveals the presence of independent modifying gene effects influencing the type 1 diabetes risk encoded by the major HLA-DQB1, -DRB1 disease loci. Hum Mol Genet 2001;10:881889. 
-27 Aghamohammadi A MM, Farhoudi A, Rezaei N, Pourpak Z, Movahedi M, Gharagozlou M, Nabavi M, Shahrokhi A: Efficacy of intravenous immunoglobulin on the prevention of pneumonia in patients with agammaglobulinemia. FEMS Immunol Med Microbiol 2004;40:113-118.

-28 Morgan JD, Hanson CG, Shearer WT: IgA deficiency progression to CVID in children. J Allergy Clin Immunol 1991;87:315.

-29 Sanal O, Ersoy F, Metin A, Tezcan I, Berkel AI, Yel L: Selective IgA deficiency with unusual features: development of common variable immunodeficiency, Sjogren's syndrome, autoimmune hemolytic anemia and immune thrombocytopenic purpura. Acta Paediatr Jpn 1995;37:526-529.

-30 Litzman J, Burianova M, Thon V, Lokaj J: Progression of selective IgA deficiency to common variable immunodeficiency in a 16 year old boy. Allergol Immunopathol (Madr) 1996;24:174-176.

- 31 Evan DI BJ: Progressive Hypogammaglobulinemia in a child born to a mother with Hodgkin's disease. Arch Dis Child 1979;54: 313-315.

-32 Slyper AH, Pietryga D: Conversion of selective IgA deficiency to common variable immunodeficiency in an adolescent female with $18 \mathrm{q}$ deletion syndrome. Eur J Pediatr 1997; 156:155-156.

-33 Ozkan H, Atlihan F, Genel F, Targan S, Gunvar T: IgA and/or IgG subclass deficiency in children with recurrent respiratory infections and its relationship with chronic pulmonary damage. J Investig Allergol Clin Immunol 2005; 15:69-74.

-34 Johnson ML, Keeton LG, Zhu ZB, Volanakis JE, Cooper MD, Schroeder HW Jr: Agerelated changes in serum immunoglobulins in patients with familial IgA deficiency and common variable immunodeficiency (CVID). Clin Exp Immunol 1997;108:477483.

-35 Smith CI, Hammarstrom L, Lindahl M, Lockner D: Kinetics of the spontaneously occurring common variable hypogammaglobulinemia: an analysis of two individuals with previously normal immunoglobulin levels. Clin Immunol Immunopathol 1985; 37:22-29.

-36 Ishizaka A, Nakanishi M, Yamada S, Sakiyama Y, Matsumoto S: Development of hypogammaglobulinaemia in a patient with common variable immunodeficiency. Eur J Pediatr 1989;149:175-176.
37 Conley ME, Notarangelo LD, Etzioni A: Diagnostic criteria for primary immunodeficiencies. Representing PAGID (Pan-American Group for Immunodeficiency) and ESID (European Society for Immunodeficiencies). Clin Immunol 1999;93:190-197.

38 Geha RS, Notarangelo LD, Casanova JL, Chapel H, Conley ME, Fischer A, Hammarström L, Nonoyama S, Ochs HD, Puck JM, Roifman C, Seger R, Wedgwood J, International Union of Immunological Societies Primary Immunodeficiency Diseases Classification Committee: Primary immunodeficiency diseases: an update from the International Union of Immunological Societies Primary Immunodeficiency Diseases Classification Committee. J Allergy Clin Immunol 2007;120:776-794.

39 Olerup O, Aldener A, Fogdell A: HLA-DQB1 and -DQA1 typing by PCR amplification with sequence-specific primers (PCR-SSP) in 2 hours. Tissue Antigens 1993;41:119134.

40 Vorechovsky I, Zetterquist H, Paganelli R, Koskinen S, Webster AD, Bjorkander J, Smith CI, Hammarstrom L: Family and linkage study of selective IgA deficiency and common variable immunodeficiency. Clin Immunol Immunopathol 1995;77:185-192.

41 De La Concha EG, Fernandez-Arquero M, Martinez A, Vidal F, Vigil P, Conejero L, Garcia-Rodriguez MC, Fontan G: HLA class II homozygosity confers susceptibility to common variable immunodeficiency (CVID). Clin Exp Immunol 1999;116:516520.

42 Rezaei N, Aghamohammadi A, Siadat SD, Nejati M, Ahmadi H, Moin M, Pourpak Z, Kamali S, Norouzian D, Tabaraei B, Read RC: Serum bactericidal antibody response to serogroup C polysaccharide meningococcal vaccination in children with primary antibody deficiencies. Vaccine 2007;25:53085314.

43 Ryder LP, Andersen E, Svejgaard A: An HLA map of Europe. Hum Hered 1978;28:171200.

44 Hammarstrom L, Axelsson U, Bjorkander J, Hanson LA, Moller E, Smith CI: HLA antigens in selective IgA deficiency: distribution in healthy donors and patients with recurrent respiratory tract infections. Tissue Antigens 1984;24:35-39.
45 Cobain TJ, French MA, Christiansen FT, Dawkins RL: Association of IgA deficiency with HLA A28 and B14. Tissue Antigens 1983;22:151-154.

46 Preud'homme JL, Hanson LA: IgG subclass deficiency. Immunodefic Rev 1990;2:129149.

47 Rachid R, Castigli E, Geha R, Bonilla F: TACI mutation in common variable immunodeficiency and IgA deficiency. Curr Allergy Asthma Rep 2006;6:357-362.

48 Pan-Hammarstrom Q, Salzer U, Du L, Bjorkander J, Cunningham-Rundles C, Nelson D, Bacchelli C, Gaspar H, Offer S, Behrens T, Grimbacher B, Hammarstrom L: Reexamining the role of TACI coding variants in common variable immunodeficiency and selective IgA deficiency. Nat Genet 2007;39: 429-430.

49 Castigli E, Wilson S, Garibyan L, Rachid R, Bonilla F, Schneider L, Morra M, Curran J, Geha R: Reexamining the role of TACI coding variants in common variable immunodeficiency and selective IgA deficiency. Nat Genet 2007;39:430-431.

50 Candore G, Lio D, Colonna Romano G, Caruso C: Pathogenesis of autoimmune diseases associated with 8.1 ancestral haplotype: effect of multiple gene interactions. Autoimmun Rev 2002;1:29-35.

51 Dawkins RL, Christiansen FT, Kay PH, Garlepp M, McCluskey J, Hollingsworth PN, Zilko PJ: Disease associations with complotypes, supratypes and haplotypes. Immunol Rev 1983;70:1-22.

52 Behan PO: Immune disease and HLA associations with myasthenia gravis. J Neurol Neurosurg Psychiatry 1980;43:611-621.

53 Stary J, Sedlacek P, Vodvarkova S, Gasova Z, Bartunkova J: Development of common variable immunodeficiency in a patient with Evans syndrome treated by autologous stem cell transplantation. Pediatr Allergy Immunol 2003;14:334-337.

54 Heikkila M, Koistinen J, Lohman M, Koskimies S: Increased frequency of HLA-A1 and -B8 in association with total lack, but not with deficiency of serum IgA. Tissue Antigens 1984;23:280-283.

55 Cunningham-Rundles C, Brandeis WE, Pudifin DJ, Day NK, Good RA: Autoimmunity in selective IgA deficiency: relationship to anti-bovine protein antibodies, circulating immune complexes and clinical disease. Clin Exp Immunol 1981;45:299-304. 